\title{
Runoff Impact on Active Geomorphosites in Unconsolidated Substrate. A Comparison Between Landforms in Glacial and Marine Clay Sediments: Two Case Studies from the Swiss Alps and the Italian Apennines
}

\author{
Irene Bollati ${ }^{1}$ \& Emmanuel Reynard ${ }^{2}$ \& Elvidio Lupia Palmieri ${ }^{3} \&$ Manuela Pelfini $^{1}$
}

\begin{abstract}
The cultural value of geomorphological heritage (i.e., geomorphosites) is universally recognised and at the same time the interest on its mutability, as a consequence of both natural- climate and human pressure, is growing. In some cases a sudden increase in the velocity of processes can cause irreversible mod- ifications threatening the survival of sites as well as theirscien- tific value in terms of integrity. The focus of this paper is put on two types of geomorphosites (active geomorphosites and evolv- ing passive geomorphosites), in which it is possible to observe and quantify the geomorphological processes varying mainly as a response to climate change. The study cases are runoff-derived landforms on unconsolidated deposits in two morphoclimatic contexts: 'calanchi' on marine originated clays in the Italian Apennines in Mediterranean climatic context (Crete d'Arbia and Radicofani, Tuscany) and earth pyramids formed in glacial deposits in continental Alpine environment (Pyramides d'Euseigne, Canton Valais, Switzerland). In both sites, human activities have strongly contributed to landscape evolution. To investigate erosion rates, dendrogeomorphological analysis (i.e. stress indicators and root exposure analysis) were combined with traditional quantitative geomorphological techniques. Analysis of the roots exposure, well correlated with the climatic data (denudation rates are higher during wet period), show that denudation rates are lower at Pyramides d'Euseigne due to the different texture of the deposits. Unfortunately, at the moment, a comparison between the two sites based on geomorphological monitoring data is not possible due to the different time interval of analysis, and only conclusions on denudation rates coming from roots exposure are allowed. Both geomorphosites have a high scientific value (representativeness and educational exem- plarity) and are characterised by dynamicity. Providing data for modelling the sites evolution and possible decrease of their scientific value, caused by proceeding of the process itself, may be particularly significant.
\end{abstract}

Keywords Geomorphosites · Erosion rates · Dendrogeomorphology $\cdot$ Quantitativegeomorphology $\cdot$ Badlands $\cdot$ Earth pyramids

\section{Introduction}

The cultural value of geological and geomorphological heri- tage is universally recognised (Panizza and Piacente 2003; Reynard et al. 2009), and at the same time the interest on its sensitivity, as a consequence of both natural-climate and human pressure, is growing (Pelfini and Bollati 2014). Geomorphosites (Panizza 2001) are considered as all the Blandforms and landscapes that can be valued and that have a particular and significant geomorphologic attributes, which qualify them as a component of a territory's cultural heritage (in a broad sense)^(Panizza and Piacente 2003).

As for landforms, it is possible to distinguish between ac- tive (dynamic) geo(morpho)sites, sites where it is possible Bto observe and quantify the geomorphological processes $\wedge$, and passive geo(morpho)sites, sites Bno longer linked to the geomorphological and climatic conditions responsible for their own genesis^ (Reynard 2004). Both types may be consideredmeaningful from a scientific point of view (i.e., as a model of geomorphological evolution sensu Bollati et al. 2012a) be- cause they witness, respectively, present and past morphoclimatic conditions. They are also meaningfull from an educational perspective, when particular attention is direct- ed towards active geomorphosites because they allow students to understand the dynamics of the Earth (Hooke 1994; Bollati et al. 2011). Passive geomorphosites may evolve under the current morphoclimatic conditions due to the effect of surface processes different from the genetic ones (i.e.evolving passive geomorphosites according to Pelfini and Bollati 2014; Fig. 1), and so they may acquire a further value in terms of education and tourism opportunities (Bollati et al. 2012a).

Climate related geomorphical processes may vary in inten- sity over time, as a response to climate change, inducing variations in risk/impact scenarios (Bell 1998; Pelfini et al. 2009; Smith et al. 2009). Landforms, no more stable in the new cli- matic conditions, may modify their shape and evolution-rate transforming themselves into other landforms. In some cases, a sudden 
acceleration of morphogenetic processes can cause irreversible modifications of geomorphosites and threaten their survival (Hooke 1994). In this sense, active-shaping processes are the cause of impacts (degradation, dismantling, new forms) on geomorphosites (Fig. 1). When associated with tourism and cultural assets, the evolution of landforms needs also to be analysed in terms of loss of the cultural value of geomorphosites and in terms of risk, within which the tourist infrastructures and human frequentation represent the compo- nent of 'vulnerability' (Cendrero and Panizza 1999) (Fig. 1). The analysis of the geomorphosite evolution and wasting rates is also important because it contributes to the assessment of attributes such as model of geomorphological evolution, educa- tional exemplarity, integrity, features that are generally consid- ered in the assessment of the scientific value of geomorphosites (Bollati et al. 2012a). From these considerations (i.e. variation of selection attributes, risk and impact on the geomorphosites), it is clear that monitoring, quantifying and characterising the intensity and frequency of the geomorphical processes acting on sensitive geomorphosites, in different morphoclimatic/ morphogenetic contexts, may become a very important tool for the prediction of their future evolution and relative conse- quences for their attributes (Pelfini and Bollati 2014).

Among active sites of geomorphological interest, those de- veloped in unconsolidated or partially consolidated deposits may create spectacular geomorphosites. Landforms shaped by running water may form in different geological contexts, in deposits of different origin, with diverse textural and structural conditions. When climatic parameters change, the efficacy of shaping processes may vary: changes in term of quantity, dis- tribution and intensity of rainfalls induce variations in water runoff and, consequently, in the efficacy of substrate modelling. In Italy, especially along the Apennine chain, runoff on the frequent and widespread shaly outcrops of homogeneous fine sediments of marine origin has generated over time a peculiar landscape, in some cases considered as geosites (e.g. Castaldini et al. 2005; Bruno and Perrotta 2012) and at a larger scale are referred to as 'badlands', in Italian: 'calanchi' and 'biancane' (e.g. among the most famous are Crete Senesi, in the Province of Siena and Calanchi di Atri, in the Province of Teramo). This terrain is characterised by deep gullies, modelled uniformly on the deposits by running water, which become deeper with continuing erosion, which confers a 'se- vere' aspect to the landscape. Calanchi and biancane land- scapes are referred to as erosion 'hot spots' in literature (Della Seta et al. 2009); their evolution over long time, as a consequence of changes in rainfall regimes and human inter- vention, has implied the passage from gullies, characterised by very sharp edges, to rounded landforms with diffuse gravity processes (Ciccacci et al. 2008). In some geological contexts, these marine sediments are overlaid by more resistant deposits and other deposits that act as a cap rock, slowing down erosion (e.g. volcanoclastic deposits of the Valle dei Calanchi, Viterbo, Italy). On such, more resistant deposits some of the beautiful towns that characterise the Italian landscape have been built (e.g. Civita di Bagnoregio, Viterbo, Italy), provid- ing an additional cultural value to this landscape (sensu Panizza and Piacente 2003).

Another kind of landscape is created by running water act-ing on heterogeneous grain-size deposits (e.g. glacial, fluvioglacial, volcanoclastic deposits) that typically shapes earth pyramids (sensu Perna 1963), sometimes spectacularly, but not so widespread due to the particular conditions neces- sary for their formation (Perna 1963). For different reasons they can be proposed as geomorphosites (see criteria in Bollati et al. 2012a; Reynard and Coratza 2013). Their aes- thetic value justifies the origin of folkloristic names like 'Ladies with hats' or 'Demoiselles coiffées' (Heck 1985), 'Organ pipes' (Avanzini et al. 2005), 'Cheminées des Fées' (Sacco 1934) or 'Fairy chimneys' (which are tufa-erosion pyramids; Baba et al. 2005). Another peculiar additional fea- ture of these erosional landforms is their close relationship with human civilizations, as in the case of the Turkish Fairy Chimneys, where, during the Bronze Age, human settlements were associated to these natural assets (Baba et al. 2005).

Earth pyramids are more frequent in environments where glacial modelling and deposition has played an important role in shaping the landscape (e.g. some examples from the Southern Italian Alps: Postalesio Pyramids, Sondrio; Zone Pyramids, Brescia; Segonzano Pyramids, Trento), as de- scribed in a monograph by Perna (1963). The coarser compo- nents (i.e. cobbles to boulders), included in the heterogeneous grain-size deposits, act as a protection for the finer sediments that elsewhere are more rapidly removed by water runoff (Poesen et al. 1994), generating very remarkable pyramidal landforms. The best conditions for the development of these landforms is the presence of sharp and angular boulders, suchas those included in glacial deposits, which offer a better pro- tection than the rounded ones (Perna 1963). As the form of the boulders depends on the transport method and also on their lithology, the composition of the deposit and its origin have an influence on the frequency of earth pyramid formation (Perna 1963). When earth pyramids derive from the erosion of ancient moraines (e.g. Pyramides d'Euseigne; Canton Valais, Switzerland), they also bear witness to palaeogeomorphological conditions of the environment, providing information on past extensions of glaciers, as well as the spa- tial distribution and a minimum thickness of glacial deposits. Variations in water runoff play a key role in the development and evolution of both badlands and earth pyramids and may be considered dependent on climatic conditions (Perna 1963; Avanzini et al. 2005), vegetation distribution (Perna 1963; Heck 1985; Ballesteros-Cánovas et al. 2013) and textural and chemical properties of the deposit (Perna 1963; Baba et al. 2005; Vergari et al. 2013). Earth pyramids and badlands characterised by a resistant cap rock may be rapidly dismantled due to cap-rock falls (Perna 1963) (e.g. Civita di Bagnoregio, 'the dying town'). Interest in their evolution is documented by an increase in research and by the new integrated approaches involved. For example, the evolution of erosion pyramids in China over different periods has been recently 3D modelled 
through terrestrial laser scanning by Yang et al. (2011).

As mentioned above, vegetation coverage, especially trees, may control the modalities of the runoff processes but, at the same time, trees are able to record, in their growth rings, both the climatic signals and the environmental changes (Schweingruber 1996). These natural 'data loggers' allow us to obtain interesting information about badland and earth pyramid evolution (Perna 1963) and to reconstruct their recent history through dendrogeomorphological analysis. Arboreal vegetation responds to the stress induced by climate variations and geomorphical processes, recording disturbance events through growth anomalies, abrupt growth changes, compres- sion wood, etc. (e.g. Alestalo 1971; Guida et al. 2008) or through exposure of roots (e.g. Hupp and Carey 1990; Pelfini and Santilli 2006; Ballesteros-Cánovas et al. 2013; Stoffel et al. 2013). In many cases, integration of geomorphol- ogy and dendrochronological methods allows the comparison of results for common time periods and the identification and dating of previous surface movements or erosion phases (e.g. Guida et al. 2008).

In this paper, we present the results of denudation rate estimation, derived from geomorphological monitoring and dendrogeomorphological analysis in two morphoclimatic contexts, where sites of geomorphological interests (i.e. geomorphosites) are present. The investigated sites were se- lected on the basis of the different typologies of deposits on which the runoff process gives rise to important and remarkable badlands and earth pyramids (i.e. model of geomorphological evolution), where the peculiar features typical of the landforms are present (i.e. integrity, educational exemplarity) and where the interactions between the geomorphological processes and the biotic component of the environment, represented by vege- tation, are meaningful (i.e. ecological support role).

The first morphoclimatic case considered is represented by the badland landscapes of Crete d'Arbia, a sub-site of the Crete Senesi, and Radicofani (Tuscany, Italy), created by sur- face runoff on marine clay lithologies under Mediterranean climatic context (Fig. 2a). Results obtained there by Bollati et al. (2012b) are compared with the results from the Pyramides d'Euseigne (Canton Valais, Switzerland; Fig. 2b),

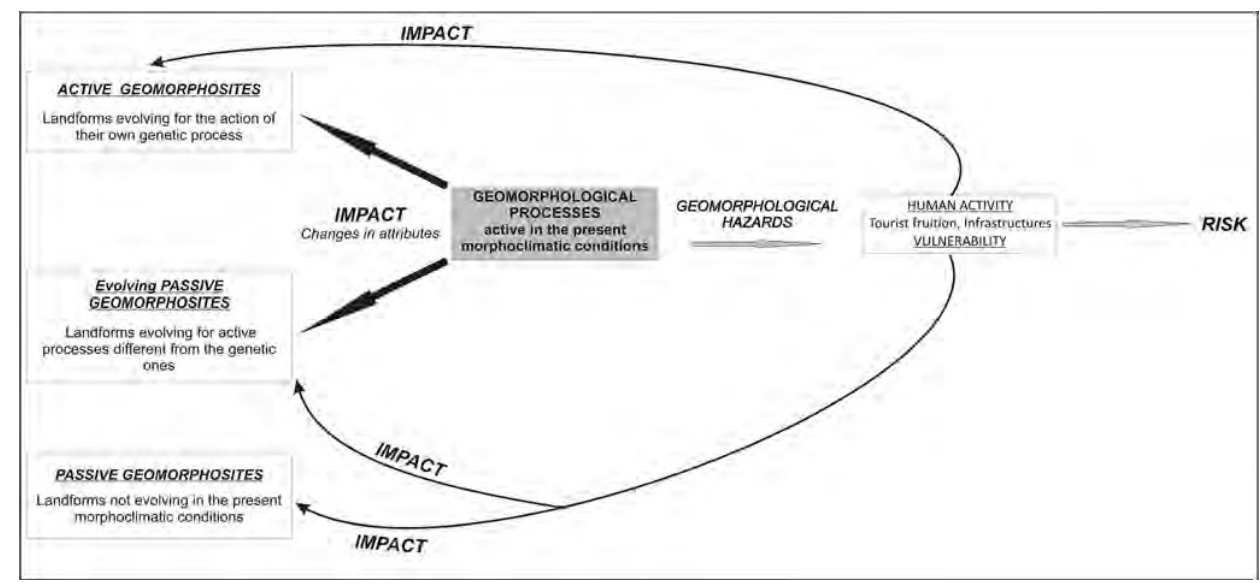

Fig. 1 Relationships between geomorphological processes, geomorphosites and human activity

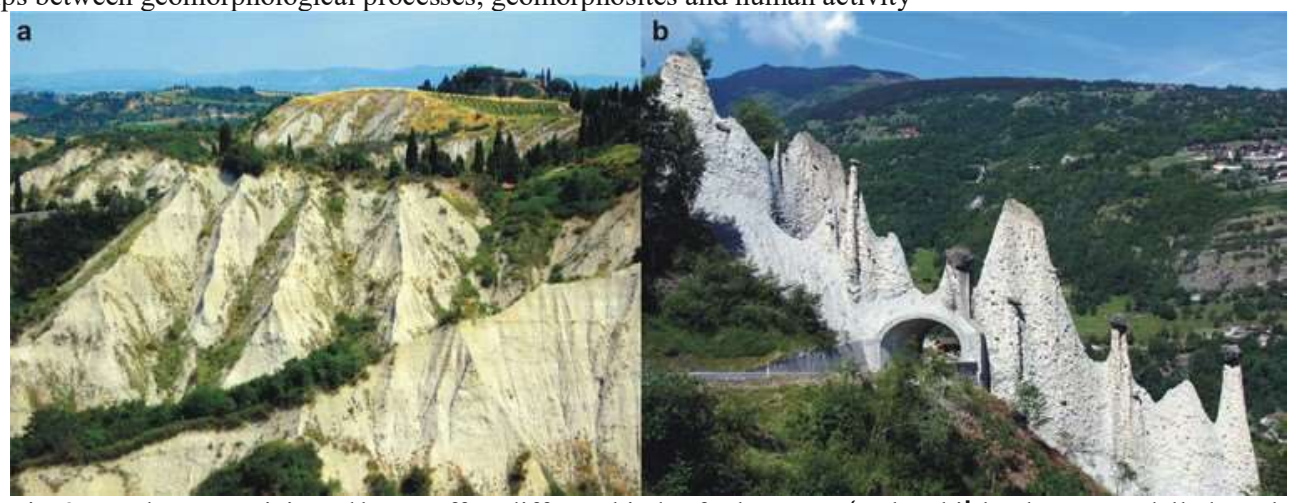

Fig. 2 Landscapes originated by runoff on different kinds of substrate. a 'Calanchi' landscape modelled on shales of marine origin with sandy intercalations at Crete d'Arbia seen from Chiusure village (Siena, Italy); b Earth pyramids modelled on glacial deposits including boulders that allow local protection from runoff at Euseigne, on the southern side of the Rhone River valley, in Canton Valais, Switzerland, seen from the main road that runs along the Hérens Valley

where glacial deposits are modelled under mountain continen- tal climate conditions. In both the studied cases, human activ- ities have also strongly contributed to the landscape evolution through deforestation, grazing and farming, land-use changes, and cropland abandonment and are the most important trig- gering factors for water erosion, tillage erosion and gravita- tional 
movements on hillslopes (Perna 1963; Heck 1985; Calzolari et al. 1997; Torri et al. 1999).

The aims of the paper are (i) to analyse erosion rates on unconsolidated or partially consolidated deposits characterised by different textures, in two morphoclimatic contexts; (ii) to evaluate the advantages of the combination of different techniques in assessing erosion rates; (iii) to dis- cuss the possible impact of active processes on the attributes of landforms defined as geomorphosites.

\section{Study Areas}

\section{Crete d'Arbia and Radicofani}

The Crete d'Arbia and Radicofani study areas are located in Tuscany on the Tyrrhenian side of the Central Apennines respectively in the Ombrone and Orcia Basins (Fig. 3a, c), which are strongly affected by water erosion and gravitational movements acting on widely outcropping Pliocene clays deposited during a marine transgression (Barberi et al. 1994) within a system of Late Miocene grabens (Radicofani Graben, Val di Chiana Graben and Tevere Graben) (Carmignani et al. 1994). Since the Late Pleistocene, these deposits have under- gone uplift due to emplacement of plutons and widespread Quaternary volcanic activity (Liotta 1996).

The variety of outcropping lithologies and the tectonic influence have determined the development of structural landforms. The present-day hilly landscape is the result of both fluvial and pervasive surface running water erosion favoured by present-day climate conditions and rapid uplift that leads to a high sediment load transported in suspension. Rill and gully erosion, along with shallow landslides, especially mudflows, lead to development of badlands (calanchi and biancane) and to soil degradation, often associated with locally developed piping phenomena (Torri and Bryan 1997).

Salvini (2008), as a result of a landscape evolution study based on remote sensing techniques, reported a noticeable reduction of the badlands area from 1954 to 2004 (84\%) in particular for Crete d'Arbia and surroundings, due to levelling practices. In addition, in the calanchi landscape of the Apennines, vegetation has been used, side by side with hydraulic interventions, to slow down erosion along mountain sides (e.g. for the area of the Monte Oliveto Maggiore Abbey, Gabbrielli 1960).

The sites of Crete d'Arbia and Radicofani are included within the Regional and Provincial Lists of geosites. The calanchi landscape of Crete d'Arbia (i.e. Monte Oliveto Maggiore and Chiusure calanchi) is also included in the Italian National Database of Geosites of the ISPRA (Istituto Superiore per la Protezione e la Ricerca Ambientale; http://sgi2.isprambiente.it/GeositiWeb/default.aspx) and constitutes a site of European interest (IT5190005), $33 \mathrm{~km}^{2}$ wide and at an elevation of about $400 \mathrm{~m}$ a.s.l. The presence of an important cultural asset in this landscape, the Monte Oliveto Maggiore Abbey, whose construction began between 1400 and 1417 A.D., confers a cultural value to the geomorphosite. Moreover, the Val d'Orcia, where Radicofani is located, was included among the cultural landscape of the UNESCO World Heritage List since 2004.

Information on local climate is based on the data of the Spedaletto meteorological station of the Regional net- work, located $25 \mathrm{~km}$ north of Radicofani and $33 \mathrm{~km}$ south of Monte Oliveto Maggiore. The study areas are characterised by mean annual rainfalls of $696 \mathrm{~mm} \mathrm{a}^{-1}$ for the time interval 1951-1996 (below the national average of $970 \mathrm{~mm} \mathrm{a}^{-1}$; source: Hydrological Year Books 


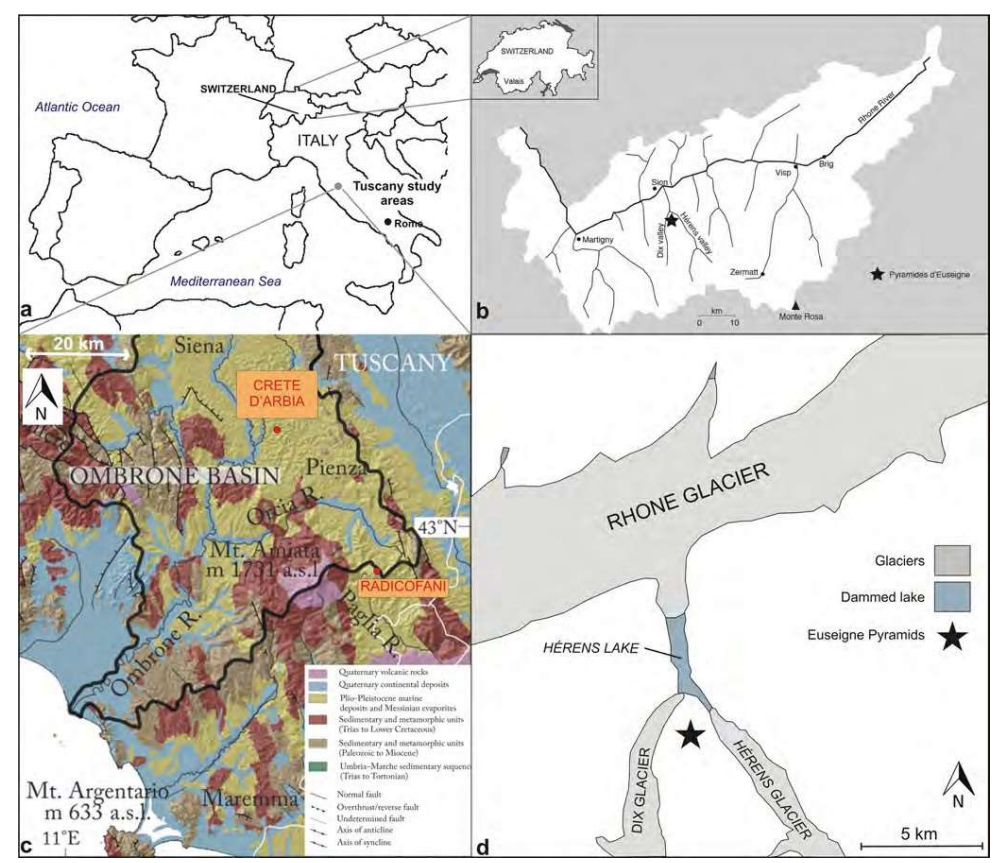

Fig. 3 Geographical location (a, b) of the study areas; c Geological setting of the Tuscany area with the position of the Crete d'Arbia and Radicofani sites (modified by Della Seta et al. 2007); d Reconstruction of the palaeoenvironment at the beginning of the Late-glacial in the Pyramides d'Euseigne area (Canton Valais, Switzerland) according to Coutterand (2012)

data), with a discontinuous distribution of rainfall during the year. The greatest number of consecutive rainy days is recorded in autumn when the rainfall regime shows a maximum in November. The minimum rainfalls are re- corded in July. Mean annual temperature is around $13{ }^{\circ} \mathrm{C}$ with a maximum in July and August. Rainfall data over the last 10 years indicates a slight decrease of the total volumes and, in particular during the recent years, marked semiarid conditions during the summer period followed by heavy rainfalls in autumn, which are recog- nized to be ideal factors for effective water erosion on clayey slopes (Della Seta et al. 2009). The Annual Aridity Index (De Martonne 1926; $(R /(T$ $+10)$ indicates the total annual rainfall $(R)$ and mean annual temperature $(T)$ for the $1999-2009$ time interval is 26.70 .

Pyramides d'Euseigne

The investigated geomorphosite is located in a southern trib- utary valley of the Rhone Valley, in Canton Valais (Fig. 3b), and it is characterised by an evident aesthetic value that led to its promotion as a geosite (Reynard et al. 2015). Earth pyramids recognition as a spectacular site of geomorphological interest dated back at least to Sacco (1934) and Perna (1963). Pyramides d'Euseigne is a very accessible site includ- ed in the Swiss inventory of geosites (site n. 53; Reynard et al.

Table 1 Reference time intervals for the data collected at Crete d'Arbia, Radicofani and Pyramides d'Euseigne areas

\begin{tabular}{lll}
\hline Geomorphosite & Method & Data timeinterval \\
\hline Crete d'Arbia & Iron pins & 1998 \\
Radicofani & & $1994-2009$ \\
Pyramides d'Euseigne & & $2010-2013$ \\
Crete d'Arbia & Roots exposure & $1998-2009$ \\
Pyramides d'Euseigne & & $1982-2009$ \\
Pyramides d'Euseigne & Photographic survey & $2009-2013$ \\
\hline
\end{tabular}

2012 ; 2015) and in the inventory of landscapes of national significance; moreover, these earth pyramids are well known as a tourist attraction. Illustrative panels are present in the adjacent parking area, and in 2010/2011 the tourist path that allows the visit to the site was refurbished and cleaned. The area considered as a geosite is about $1 \mathrm{~km}^{2}$ wide, and it is located at about $950 \mathrm{~m}$ a.s.l. The Pyramides d'Euseigne are located at the confluence of the Hérens and Dix valleys, along which respectively the Borgne and the Dixence rivers flow. Along the two confluent valleys, metamorphic rocks belonging to Middle and Upper Penninic and Austroalpine Domains (Dent Blanche) outcrop. A geomorphological map of the 
Hérens Valley has been recently published by Lambiel et al. (2015). Down valley, the confluence of the Hérens valley with the Rhone River valley, is characterised by the presence of a postglacial gorge. Deltaic and lacustrine sed- iments also outcrop as a consequence of the barrier action of the thick Rhone glacier during the last stages of the Würm glaciation, when the tributary valleys were already partly deglaciated (Rumeling stage of the Rhone glacier; Dorthe -Monachon 1993; Coutterand 2012). The conse- quence of the damming was the formation of a wide glacial lake (Coutterand 2012; Fig. 3d).

The Pyramides d'Euseigne represents the remnants of a Late-glacial lateral moraine of the Dix glacier that lie above deltaic deposits dipping towards the palaeolake area

Fig. 4 Dendrogeomorphological

analysis at the study sites. a, b

View of the sampling sites

respectively at Crete d'Arbia,

where Pinus pinea L. were

studied, and the Pyramides

d'Euseigne, where Larix decidua

(Mill.) are present in the upper

part of the pyramids, in the area

immediately above the main road;

$c, d$ Roots exposed respectively at

Crete d'Arbia and Pyramides

d'Euseigne (Photos by I. Bollati, 2010)

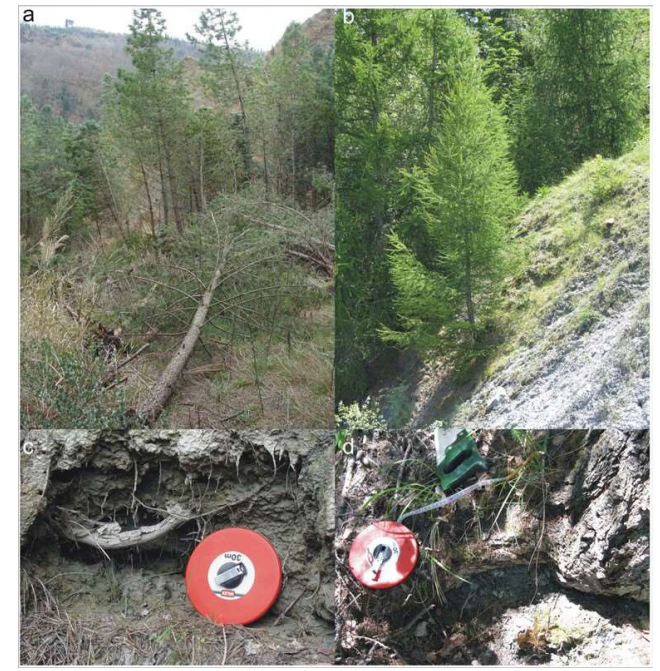

Table 2 Comparison among the local erosion rates (LERs) and average erosion rates (AERs) ob- tained at Crete d'Arbia (Tuscany, Italy) and Pyramides d'Euseigne (Valais, Switzerland) using root exposure

\begin{tabular}{lllll}
\hline & Time interval & Crete d'arbia & Time interval & Euseigne \\
\hline Local erosion rates (LERs) $\left(\mathrm{cm} \mathrm{y}^{-1}\right)$ & & & $1982-2009$ & 0.71 \\
& & & $1987-2009$ & 0.30 \\
& & & $1993-2009$ & 0.47 \\
& $1998-2009$ & 0.27 & $1998-2009$ & 0.83 \\
& $2003-2009$ & 1.58 & & \\
Average erosion rates (AERs) $\left(\mathrm{cm} \mathrm{y}^{-1}\right)$ & $1998-2009$ & $3.25-3.75$ & & \multirow{2}{*}{$19092-58$} \\
\hline
\end{tabular}

The capital letters indicate the iron pins as reported in Fig. 6 (Coutterand 2012). After the glacial retreat, the interstitial pores of the glacial deposits were filled with fine and well- cemented material. As mentioned before, in the case of different grain-size deposits, like the glacial tills of Euseigne, coars- er elements (cobbles to boulders) act as protection for the finer sediments that are more rapidly removed under water runoff where the boulders-caps are not present. The earth pyramids are characterised by an elongated shape (Fig. 2b), following the morainic ridge, and often they are connected each other by thin residual edges. The greater part of earth pyramids may be classified according to Perna (1963, p.21): 'b' ('group of con- nected earth pyramids where one of them lost the boulder cap and is vanishing') and 'm' ('squat pyramid with a very big boulder cap').

The climate of the Euseigne area has been estimated based on two meteorological stations of the national network MeteoSwiss: Héremence (rainfall data; $1 \mathrm{~km}$ northwest to Euseigne, $1260 \mathrm{~m}$ a.s.l.) and Sion (temperatures and rainfall data; $7.5 \mathrm{~km}$ northwest to Euseigne, $482 \mathrm{~m}$ a.s.1.). During the time interval 1981-2010, mean annual rainfall at Hérémence was 786 $\mathrm{mm} \mathrm{a}^{-1}$. The rainfalls are distributed quite homoge- neously over the year (mean monthly rainfall; $65.5 \mathrm{~mm} \mathrm{a}^{-1}$ ) with maximum values recorded during Summer (225 mm in June-August period). In Sion, mean annual rainfall was $603 \mathrm{~mm}$ $\mathrm{a}^{-1}$. Considering a rainfall gradient of $23.5 \mathrm{~mm} / 100 \mathrm{~m}$ between Sion and Hérémence stations, mean annual rainfall at the Pyramides d'Euseigne can be estimated to be $716 \mathrm{~mm} \mathrm{a}^{-1}$. Based on Sion mean annual temperature $\left(10.1{ }^{\circ} \mathrm{C}\right)$ and temperature gradients proposed by Bouët $\left(1985 ; 0.46^{\circ} \mathrm{C} / 100 \mathrm{~m}\right)$, mean annual temperature for the time interval 1981-2010 is around $8^{\circ} \mathrm{C}$, with a maximum in July and August. The Annual Aridity Index (De Martonne 1926) is 39.7 for the time interval $1981-2010$.

Methods 
The investigation method consists in combining techniques of quantitative geomorphology and dendrogeomorphology, use- ful for erosion rate estimation and wider environmentalanalyses. The time intervals of data collection are partly dif- ferent (Table 1), and for this reason, only overlapping data will be compared in the discussion of results.

At the site of Pyramides d'Euseigne, along with the sam- pling for the different laboratory analysis, a photographic survey at fixed locations was carried out over the time interval 2009-2013 in order to detect macroscopic variations of single portions of the geomorphosite. In detail, the applied method- ologies are as follows:

i) At the Pyramides d'Euseigne site, sampling of sedi- ments for grain-size analysis was conducted at selected outcrops up to a $1 \mathrm{~km}$ maximum from the delimited geosite area. In order to characterise the complete framework of the different deposits in the area, this sampling was carried out in both glacial till and in the deltaic deposits. The grainsize analysis was carried out by wet and dry sieving for both sand and gravel frac- tions, and for the fraction $<63 \mu \mathrm{m}$ by pipette method, based on the 'Stokes' sedimentation rates. The samples, on which gravel and clay/silt specific grainsize proce- dures were applied, were selected as a function of the percentage of the two grain size intervals obtained by sand sieving.

ii) Erosion rates monitoring on shale and glacial de- posits through placement of iron pins was carried out in different locations in the study areas in order to determine areas of prevalent erosion and of prev- alent accumulation (see detailed methods in Della Seta et al. 2007 and references herein). In the Pyramides d'Euseigne site, the pins were also placed on thin ridges between pyramids, measuring both the emersion of the pin from the ground and the ridge geometry. The data presented in this paper come from field campaigns in the area of Radicofani conducted during the time interval 1994-2009 while at Pyramides d'Euseigne, the geo- morphological monitoring data derive from the 2010-2013 period and only these preliminary re- sults will be illustrated.

Fig. 5 Main textural features of the glacial deposits of Euseigne earth pyramids and surroundings areas. a Earth pillar without the boulder cap; the emersion of a metric boulder is visible, like those that usually constitute the cap of pyramids; $b$ Detail of the most widespread facies of glacial deposits in the pyramids and surroundings; c, d Local distribution and detail of channel troughs with open-work deposits of rounded cobbles; e

Stratification of silt with sand and gravelly sand levels; f Different grain-size deposits rich in cobbles and boulders; $\mathrm{g}$, h Stratified facies of silty sand with gravel, silt with sand: outcrop and detail. (Photos by I. Bollati, 2010)

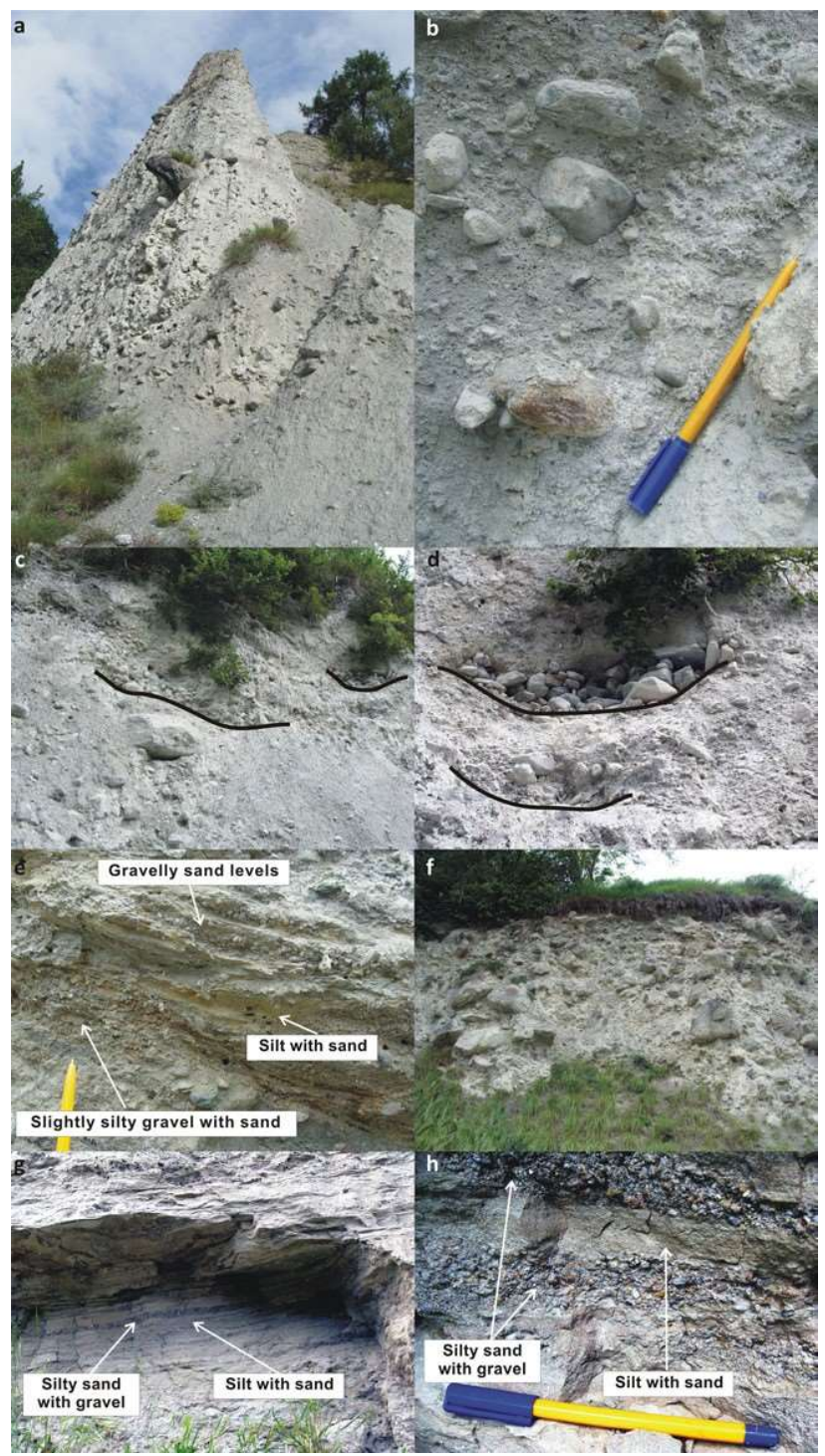


ii) Dendrochronological analysis on trees (Fig. 4a, b) and exposed roots (Fig. 4c, d) was concentrated on 45 trees of the species Pinus pinea L. at Crete d'Arbia and on 13 trees of the species of Larix decidua (Mill.) at Pyramides d'Euseigne, and depended on the number of trees close to the active sites. The sampling of roots was especially aimed at the estimation of erosion rates (e.g. Hupp and Carey 1990; Pelfini and Santilli 2006; Ballesteros-Cánovas et al. 2013). Samples from trunks and roots were made using an increment borer. The cores extracted from the trunks were collected at the standard height of $1.30 \mathrm{~m}$ (chest height). In addition,

Table 3 Erosion rates calculated at the Pyramides d'Euseigne geomorphosite by means of iron pins monitoring for the time interval (2010-2013)

\begin{tabular}{llllllll}
\hline Iron pins AERs (cm/year) & \multicolumn{1}{l}{} & & & & \\
\hline Geomorphosite ared & $2010-2011$ & $2011-2012$ & $2012-2013$ & Min & Max & Average \\
Middle area, above the trail (A, B) & 0.0 & 0.0 & - & 0.0 & 0.00 & 0.00 \\
Middle area, below the trail (C, D, E) & - & 0.0 & 4.5 & 0.0 & 4.5 & 2.25 \\
Lower area (F, G) & 0.0 & -1.0 & 0.0 & -1.0 & 0.0 & -0.33 \\
Upper area (H, I) & 10.5 & 5.0 & 3.0 & 3.0 & 10.5 & 6.17 \\
Total area & 4.20 & 0.5 & 6 & 0.5 & 6 & 3.57 \\
\end{tabular}

disks and cores were cut from exposed roots and lengths of root exposure, and distance from the ground was measured to quantify the removed sediment. For the dendrochronological investigations, tree-ring widths were measured (accurate to $0.01 \mathrm{~mm}$ ) using the LINTAB and TSAP systems (Rinn 1996) and image analysis with WinDENDRO software (Regent Instruments Inc. 2001). The cross-dating of the dendro- chronological series was statistically processed visually with TSAP and using the COFECHA program (Holmes et al. 1986). Since the growth curves present an evident growth trend, the removal was done by indexing the

Fig. 6 Example of results of the iron pin monitoring across the Pyramides d'Euseigne area. In the general view of the geomorphosite, the location of each iron pin and the tourist trail (white dotted line) are indicated. Some pins were lost during the survey years as a result of the refurbishment of the tourist trail, and others were tilted and fell, in some cases hit by blocks ( $\mathrm{H}$ and F). The white hole circled indicates the area of dendrogeomorphological sampling on Larixdecidua (Mill.) (Photos by I. Bollati, different survey years)

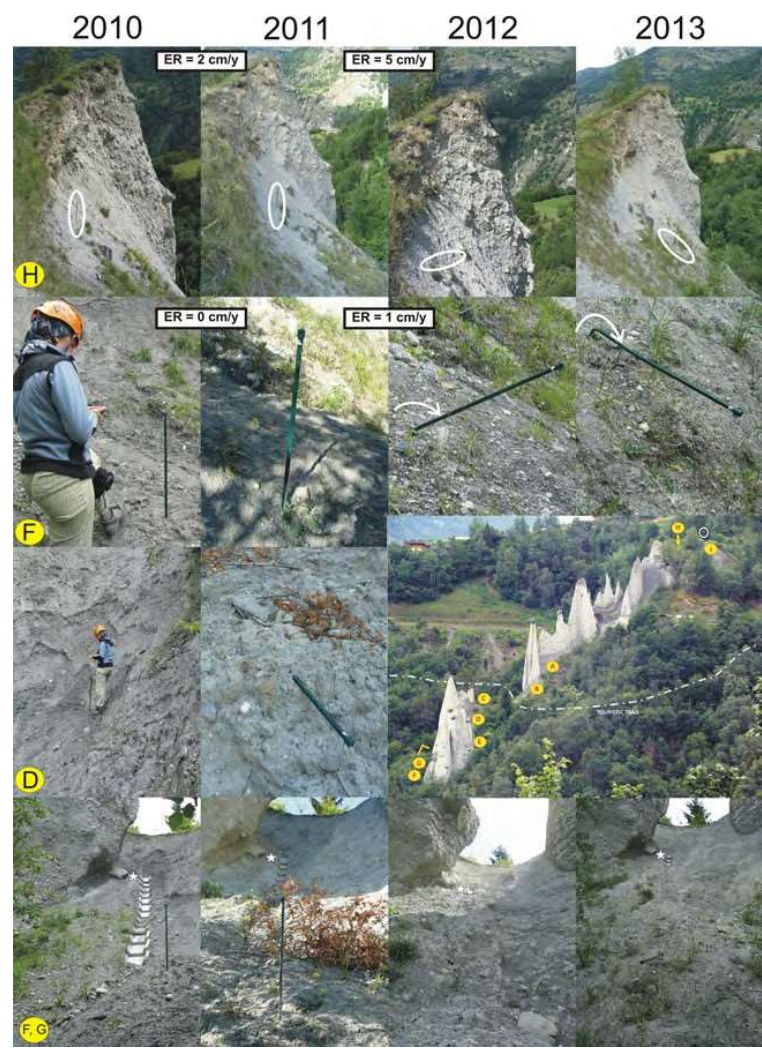




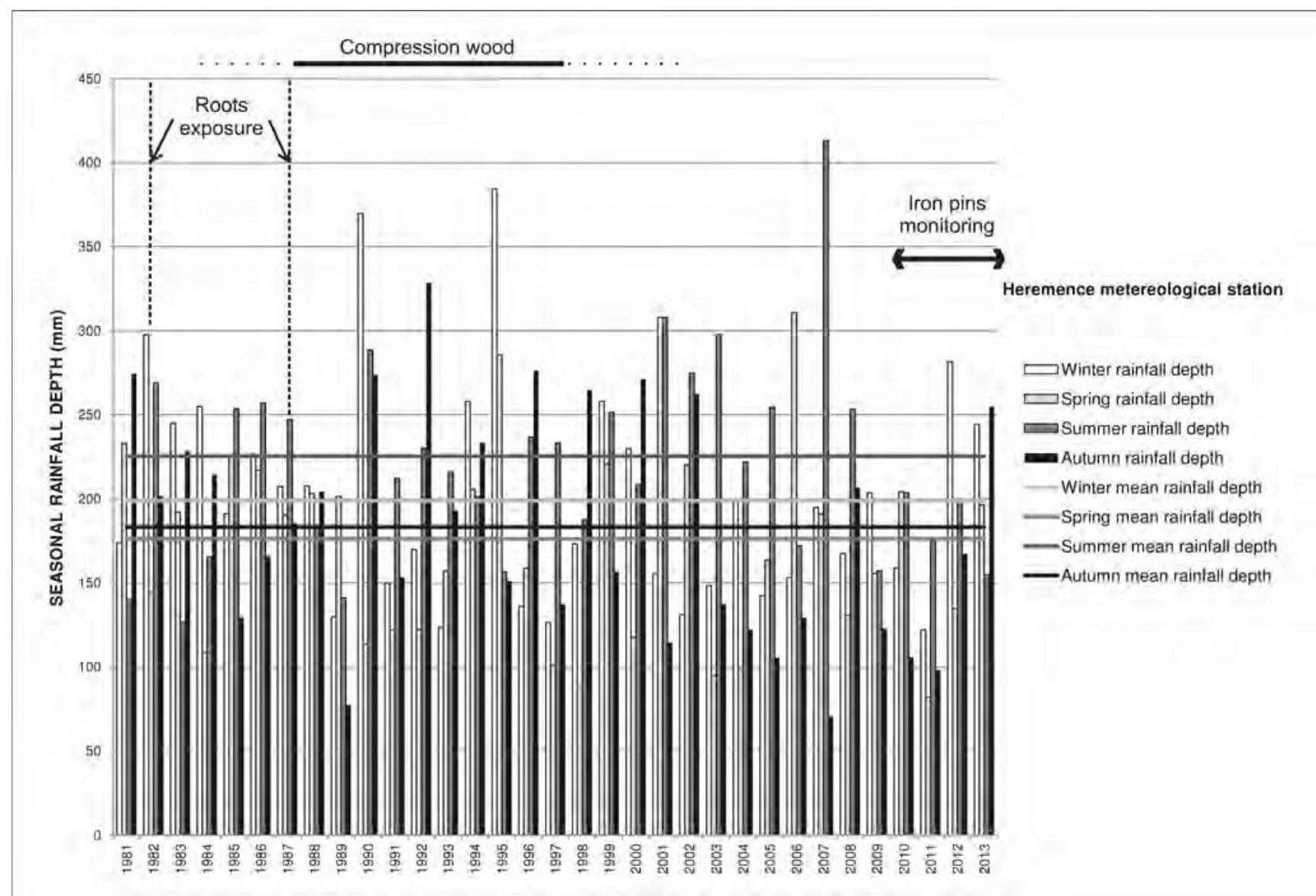

Fig. 7 Comparison of seasonal rainfall depths from the Hérémence meteorological station and dendrogeomorphological data (root exposure and wood compression). The time interval of iron pins monitoring,

presence of wood compression and root exposure are indicated. The reported average seasonal values of rainfalls are referred to the $1981-2010$ time interval. Climatic data: MeteoSwiss

hronology using ARSTAN (Cook 1985) through the application of an individual spline. Compression wood (Timell 1986) that allows the localization in space and time of stress sources as creep-like movements was described and dated. Roots were also sampled in more detail to carry out morphometric analysis and to esti- mate the erosion rates due to surface running water that is responsible for the exposure of the roots and conse- quent changes in root micromorphology (Alestalo 1971; Hupp and Carey 1990; Gärtner et al. 2001; Gärtner 2007). The change in root micromorphology consists mainly in the transition from production of root-type wood to a trunk-type wood, with the distinction in early and latewood. Thus, applying the equation of Hupp and Carey (1990) $(E=\mathrm{D} / \mathrm{A})$, it is possible to obtain the erosion rate $(E)$ by dividing the distance $(D)$ between the actual ground surface and the tree root collars by the age $(A)$ of the micro-morphologic change in root. Each root growth curve was compared to the corresponding tree growth curve in order to obtain the minimum exposure date (for detailed methodology, see Pelfini and Santilli 2006). Hence, local erosion rates (LERs), i.e. the local values in correspondence of each root, and average erosion rates (AERs), i.e. the average value for the area, were calc ulated. Dendrogeomorphological analysis was performed in 2009 and 2010 at Crete d'Arbia and in 2010 at Pyramides d'Euseigne.

iii) The (i) and (ii) phases were accompanied by a compar- ison with climatic data, which aimed to confirm if, in both study cases, specific climatic patterns can induce intensification in erosion rates (according to the results obtained by Della Seta et al. $(2007 ; 2009)$ and Bollati et al. (2012b)).

\section{Results}

\section{Crete d'Arbia and Radicofani}

Bollati et al. (2012b) detailed the results of the investigations into the Mediterranean morphoclimatic context. Only a brief summary of the most relevant data is reported here in order to compare erosion data from root exposure with those obtained at the second study site. 
The value of denudation for the Radicofani area over the entire period of monitoring (1994-2009) is 1.65-

$1.96 \mathrm{~cm}_{\text {year }}{ }^{-1}$ (maximum value $8 \mathrm{~cm}_{\text {year }}{ }^{-1}$; minimum value $0 \mathrm{~cm}_{\text {year }}{ }^{-1}$ ) and specifically for the Monte Oliveto Maggiore pins (1998) is 1-1.5 $\mathrm{cm} \mathrm{year}^{-1}$. The LERs (Table 2) obtained through dendrochronological investigations close to Monte Oliveto Maggiore are differentiated along the investigated slope $\left(0.27-3.75 \mathrm{~cm} \mathrm{year}^{-1}\right)$. The denudation values, charac- teristic of the lower portion of the hillslope (1.58 $\left.\mathrm{cmyear}^{-1} ; 2003-2009\right)$, and the AERs (Table 2) $\left(1.78 \mathrm{~cm} \mathrm{year}^{-1} ; 1998-2009\right)$ that include the resolution of the entire period of expo- sure are of the same magnitude order of the AERs recorded by iron pins method in the Radicofani area (1.65-1.96 $\mathrm{cm} \mathrm{year}^{-1}$; 1994-2009).

Not only do erosion rates derived from root exposure tes- tify to the heterogeneity of the runoff processes inside single sites, dendrogeomorphological indicators (i.e. compression wood and anomaly index) also confirm this character. In particular, the correspondence of the period of intensification of denudation rates, recorded by iron pins and corresponding to a couplet of dry-wet years (e.g. 2001/2002) to the presence of negative of growth anomalies, characterises the most of the trees along the slope. Moreover, in the central portion of the slope during the 1-year time interval between fieldwork (2009-2010), many trees fell (Fig. 4a). These trees had been characterised by persistent compression wood since at least 2005. In this portion of the slope, the minimum erosion rates for the period 1998-2009 (i.e. $0.27 \mathrm{~cm}_{\text {year }}{ }^{-1}$ ), estimated by root exposure, were recorded, and for this reason, the contri- bution of subsurface piping process may beinvoked.

\section{Pyramides d'Euseigne}

The geomorphosite of the Pyramides d'Euseigne may be con- sidered apparently 'static' when observing the photographs tak- en during annual survey at fixed points, especially if looking at a single landform (i.e. a single pyramid). The characterisation of the deposits, observed qualitatively in the field and analysed quantitatively through grain-size analysis, allowed the distinc- tion of two main facies in the investigated area $\left(1 \mathrm{~km}^{2}\right)$.

The most widespread facies is represented by a chaotic deposit with silty matrix (20-40\%) in which coarse compo- nents ( $25 \%$ pebbles to $5 \%$ boulders) are locally abundant and not spread homogeneously (Fig. 5a, b, f). The larger boulders are isolated and they are expected to be responsible, with the proceeding of the runoff, of the creation of new pyramids as primary or secondary (within primary ones) form (Fig. 5a). The material that accumulates between the rills and in the lower portion of the pyramids does not present a homoge- neous grain-size characterisation (gravel, 20-60\%; sand 14-55\%; silt, 30-48\%). Across the whole area, the surface of the pyramids is covered by a local hardening (Perna 1963), which confers a major resistance to the deposit, and by superficial fractures, present as a consequence of the desiccation of fine material. Locally, where the chaotic facies outcrops, concen- trated rounded pebbles and cobbles fill metric hollows (Fig. 5c, d) and deposits without matrix are locally present, testifying to water action remobilization of the original depos- it. The second facies presents a clear layering with an alterna- tion of centimetric to decimetric bands of silty sand and silty sand with gravel (sand, $55 \%$; gravel, $30 \%$; silt, $15 \%$ ) (Fig. 5e, g, h).

Earth pyramids are developing mainly in the overlying chaotic facies representing the remnants of a Late-glacial lat- eral moraine of the Dix Glacier (Coutterand 2012). Where the stratification is evident and the grain size varies mainly from silt to sand, i.e. in the deposits relative to the deltaic environ- ment proximal to the palaeolake (Coutterand 2012), the pyra- mids do not form.

The preliminary results derived from 3 years of moni- toring through iron pins are reported in Table 3 and in Fig. 6 . Some of the iron pins were tilted and eventually fell naturally and progressively (Fig. 6; iron pin $\mathrm{H}$ ), and in the lower part, one iron pin was tilted and hit by falling blocks, presumably from the middle portion of the site (Fig. 6; iron pin F). Generally, non-homogeneous erosion rates were recorded all over the site (minimum value $0 \mathrm{~cm}^{-1} \mathrm{year}^{-1}$-maximum value $10.5 \mathrm{~cm} \mathrm{year}^{-1}$ ), and they are higher in the upper part above the main road (3-

$10.5 \mathrm{~cm} \mathrm{year}^{-1}$ ) (Fig. 6; iron pins $\mathrm{H}$ and I). Even though the monitoring interval has been only 3 years, differences between years were recorded. The maximum average ero- sion rate across the site was recorded in 2013 (6 $\left.\mathrm{cm} \mathrm{year}^{-1}\right)$ and the minimum in $2012\left(0.5 \mathrm{~cm} \mathrm{year}^{-1}\right)$. The thinning of the ridges width follows this trend: maximum in $2013\left(2.03 \mathrm{~cm} \mathrm{year}^{-1}\right)$ and mini- mum in $2012\left(0.5 \mathrm{~cm} \mathrm{year}{ }^{-1}\right)$. In the lower part of the py ra mid s are a, accumulation was me as ure d $\left(1 \mathrm{~cm} \mathrm{year}^{-1}\right)$ especially in 2012 (Fig. 6; iron pins D, F). Analysis of the roots indicates that they were exposed since the early years of the tree's growth and their mean chronology cross-dates well with that of the trees. In particular, root ex- posure dates back to 1982 and 1998. LERs along the slope are reported in Table 2 as well as the AERs, calculated for the time interval 1982-2010 $\left(0.58 \mathrm{~cm}\right.$ year $\left.{ }^{-1}\right)$. The integration of cli- matic, dendrogeomorphological (root exposure and compres- sion wood) and iron pins monitoring data is reported in Fig. 7 . The time interval of root exposure coincides with a period when both seasonal and annual rainfall levels had been over the 19812010 average for several consecutive years. Compression wood, testifying to mechanical stress on trees, was recorded mainly in the time interval 1984-2002 with a higher incidence during 1987-1998, a period during which seasonal and annual rainfall levels had been over the average for several consecutive years. 


\section{Discussion}

This integrated approach of dendrogeomorphological analysis and geomorphological monitoring was aimed at (i) estimating rates of evolution at sites characterised by different unconsol- idated substrate and under different climatic conditions; (ii) determining the different contributions of each technique when assessing denudation rates. The different morphoclimatic and morphogenetic contexts and beside the difference in the modelled deposits allowed the analysis of the obtained denudation rates as follows:

i) Average values of erosion rate calculated through dif- ferent methodologies are comparable at the level of a single site, only where the iron pin monitoring was carried out for a sufficient time interval (e.g., 15 years) to produce timecomparable values, as in at Radicofani. Through iron pin monitoring, it is possible to record annually or seasonally the value of denudation, regis- tering single moments of erosion intensification, i.e., a step-like trend of denudation (Della Seta et al. 2007), while based on root exposure, only a mean denudation value (i.e. AERs) for the area over the time interval 'exposure year-sampling year' or LERs for the different portions of the slope may be calculated. In this sense, the average erosion rates obtained for the Radicofani morphoclimatic context through iron pins for the time period 1994-2009 (i.e. 1.65-1.69 $\mathrm{cm} \mathrm{year}^{-1}$ ) and the AERs obtained through roots exposure for the time period 1998-2009 $\left(1.78 \mathrm{~cm} \mathrm{year}^{-1}\right)$ are of the same order of magnitude;

ii) A comparison may be proposed between Crete d'Arbia and Pyramides d'Euseigne for denudation rates obtain- ed through root exposure over the long time period. As reported by Stoffel et al. (2013) in a recent review on erosion calculation by means of roots exposure in dif- ferent environments, the values obtained by different authors are function of the morphoclimatic and mor- phogenetic contexts and may vary between 0.15 and

$1.35 \mathrm{~cm}$ year $^{-1}$. Generally at Crete d'Arbia, roots are exposed in different years, and the amounts of removed sediments are different along the slope providing differ- ent LERs $\left(0.27-3.75 \mathrm{~cm}_{\text {year }}{ }^{-1}\right.$; Table 2). The LERs at Euseigne are less variable (0.30-0.83 $\left.\mathrm{cm} \mathrm{year}^{-1}\right)$. In the case of Pyramides d'Euseigne, the elongated shape of the pyramid distribution, following the ancient moraine ridge, allowed us to collect data on exposed root only in the upper and middle part where erosion was severe, while in the lower part, because of prevailing accumulation, exposed roots were not found.

The time interval does not precisely overlap between Crete d'Arbia and Euseigne (see Table 1), but the root exposure method does not allow the extrapolation of a time sub-interval for sediment removal. However, a comparison between results is still proposed, in partic- ular using LERs (see Table 2). In general, both the LERs and AERs obtained through root exposure are higher at Crete d'Arbia (slight to severe erosion according to Zachar 1982) respect to those calculated for the Pyramides d'Euseigne (slight erosion according to Zachar 1982). This is probably due to the different textures and compaction of the deposits and because of the cementation the glacial deposits underwent after the glacial retreat, by fine material, conferring imperme- ability and favouring the formation of pyramids forma- tion (Perna 1963). Also, other local variables (e.g. to- pographic relief, slope aspect, climate) may be taken into account, and the erosion process may be differen- tiated along the single slope. For example, considering in Table 2 the time interval 1998-2009, which is the only one perfectly overlapping between the two series, the LERs at Crete d'Arbia are lower than at Euseigne contrary to the general LERs and AERs trend. This is probably due to the fact that, as above mentioned, the Crete d'Arbia slope section, in which roots are exposed, is characterised by a piping process rather than superfi- cial runoff (see Bollati et al. 2012b);

iii) The comparison of the values obtained through iron pin monitoring between the two sites is not reasonable for the different time intervals. The annual recorded values of denudation at Pyramides d'Euseigne during the time interval 2010-2013, a period of seasonal annual rainfall below the means for the 1981-2010 time interval, are variable throughout the pyramids area $\left(0.5-6 \mathrm{~cm} \mathrm{year}^{-1}\right)$. The collection of data through iron pin monitoring will continue in both the study areas;

iv) The trend of seasonal rainfall levels looks like an influ- ence in both environments. At Crete d'Arbia and Radicofani, the coupling of dry-wet years is demon- strated to trigger erosion as testified by both iron pin monitoring and dendrogeomorphological indicators (i.e. compression wood and anomaly index), and the contribution of a piping process was detected. The Pyramides d'Euseigne is characterised by an annual rainfall regime typical of other areas where these land- forms are present (Perna 1963). The presence of com- pression wood in trees follows a period of roots expo- sure (1987-1994) and may be also influenced by the instability generated by root exposure. Moreover, it cor- responds to a time interval characterised by high annual rainfall levels that may have triggered instability along the slope where the trees are located.

In the framework of geomorphosites research, as mentioned in the introduction, new terms have recently been 
proposed concerning activity of the sites. In par- ticular, Reynard (2004) proposed the use of the follow- ing terminology: i) active geo(morpho)sites for sites where it is possible 'to observe and quantify the geo- morphological processes'; ii) passive geo(morpho)sites for sites 'no longer linked to the geomorphological and climatic conditions responsible for their own genesis'. Pelfini and Bollati (2014) added a new category: evolv- ing passive geomorphosites for those passive geomorphosites that continue to evolve under the cur- rent morphoclimatic conditions due to the effect of sur- face processes different from the geneticones.

In terms of geoheritage, the calanchi landscapes of Crete d'Arbia and Radicofani may be considered among the active geomorphosites that are evolving rap- idly and where annual modifications are recorded. At Crete d'Arbia, trees were involved in falls and also the main road, which runs along the ridge above the sample site, is affected and undermined by falls with consequent risk issues. As revealed by the results of the analysis conducted by Perna ( 1963) on morphoclimatic contexts similar to Euseigne, the evo- lution rates of earth pyramids depends strictly on local conditions (e.g. the position with respect to the hydro- graphic pattern) and the author proposed a classification as slowly evolving and rapidly evolving pyramids, without indications on the discriminating values of ero- sion rate between the two categories. The Pyramides d'Euseigne appears to be quiescent across a brief time interval (i.e. 4 years) when considering the periodical photograph survey conducted at level of a single pyra- mid. However, according to iron pin monitoring for the period 2010-2013, modifications occurring to the site through this time period have to be considered even if AERs over a longer period are lower than those at Radicofani. Following the classification proposed by Pelfini and Bollati (2014), these landforms may be con- sidered as evolving passive geomorphosites because past moraine landforms are currently modelled by run- ning waters, a different process when compared to the genetic one.

The falling of blocks of different grain size is possi- ble, as testified by the hit iron pins, and local incidences of intense runoff at the base of pyramids, undermining the stability of the pyramid sides, were detected and may favour the block falls (Perna 1963). In this extreme case, in which boulders located at the top of the pyra- mids fall, features like integrity, rarity, model of geo- morphologicalevolution or educational exemplarity of the geomorphosite may undergo adecrease, influenc- ing both the scientific and global values of the site (see Pelfini and Bollati 2014). The results and considerations on attribute variations of geomorphosites (Bollati et al. 2012a) may be useful for the site man- agement, and this kind of processes should be taken into account because they may also increase risks in the context of tourist enjoyment.

\section{Conclusions}

The natural processes, proceeding with their own rates, may undergo modifications as a consequence of climate change (e.g. intensification of runoff, glacial shrinkage) and human intervention on natural environment (e.g. deforestation, road cuts). If affecting geomorphosites, these modifications should be taken into account during evaluation phases because they may influence values used during assessment procedures (e.g., model of geomorphological value, educational exemplarity, integrity). Research regarding geomorphosites up to now have focused mainly on census, quantitative evaluation methodologies and educational applications, without consid- ering both changes within the sites and the possibility of integrating data of evolution estimation in the evaluation procedures considering also the context of developing educational applications and the management of sites for tourist enjoyment (see Reynard and Coratza 2013 and references herein).

In this context, the combination of various investigation techniques may allow the comparison of sites located in different morphoclimatic and morphogenetic contexts, while considering the precise requirements for each investigating methodology. However, the different temporal extension of the geomorphological monitoring between the two areas did not allow a direct comparison among the study sites, but con- sidering data from the analysis of root exposure, the AERs and LERs were demonstrated to be lower at Pyramides d'Euseigne, due to the different texture of the deposits, and to be well correlated with the climatic data. Hence, dendrogeomorphology has provided an added value to the traditional geomorphological researches.

As highlighted for the first time by Perna (1963), badlands and earth pyramids share the common feature of being meaningful erosion sites and, especially in the second case, the evolution rates depend on closely on local conditions which can vary significantly from case to case. Both the studied natural assets may be considered to have a high scientific and educational value, characterised by dynamicity and definable as active (i.e., Crete d'Arbia and Radicofani) or evolving passive (i.e., Pyramides d'Euseigne) geomorphosites according to the geomorphological process itself. Obtaining values for erosion rates is useful for both for site management 
(e.g. geoconservation purposes, hazards evaluation along touristic trails, etc.) and for disseminating scientific con- cepts about the dynamism of geomorphosites, including accelerating factors of geomorphological processes, for example in relation to climate change.

Acknowledgments The research was carried out in the framework of the PRIN 2010-2011 project (grant number 2010AYKTAB_006) 'Re- sponse of morphoclimatic system dynamics to global changes and related geomorphological hazards' and the PRIN 2007 project 'Development of an integrated model for a preventive assessment of soil degradation pro- cesses in Mediterranean environment', funded by the Ministero Istruzione Università Ricerca (MIUR). The authors are grateful to Prof. Maurizio Del Monte, Prof. Paola Fredi, Dr. Marta Della Seta, Dr. Francesca Vergari for the collaboration during the scientific research con- ducted in Tuscany; they are grateful also to Dr. Jean-Michel Fallot (Uni- versity of Lausanne) and Prof. Massimiliano Fazzini for the preparation and sharing of climatic data and to Dr. Davide Cagnin and Dr. Marco Pellegrini for the assistance during the field surveys at Pyramides d'Euseigne. They thank two anonymous reviewers for useful comments on the original version of the manuscript. They are grateful to the Canton of Valais administration (Landscape and Forest Service, director: M. Olivier Guex) for authorising us to investigate the protected area of Pyramides d'Euseigne.

\section{References}

Alestalo J(1971) Dendrochronological interpretation of geomorphic pro- cesses. Fennia 105:1-140

Avanzini M, Carton A, Seppi R, Tomasoni R (2005) Geomorphosites in Trentino: a first census. Il Quaternario 18(1):63-78

Baba A, Kaya A, Turk N (2005) Fairy chimneys Cappadocia and their engineering properties. J Appl Sci 5:800-805

Ballesteros-Cánovas JA, Bodoque JM, Lucía A, Martín-Duque JF, Díez- Herrero A, Ruiz-Villa nueva V, Genova M (2013) Dendrogeomorphology in badlands: methods, case studies and pros- pects. Catena 106:113-122

Barberi F, Buonasorte G, Cioni R, Fiordalisi A, Foresi L, Iaccarino S, Laurenzi MA, Sbrana A, Vernia L, Villa IM (1994) Plio-Pleistocene geological evolution of the geothermal area of Tuscany and Latium. Mem Descr Carta Geol Ital 49:77-134

Bell FJ (1998) Environmental geology. Principles and practice. Blackwell, Oxford

Bollati I, Pelfini M, Pellegrini L, Bazzi A, Duci G (2011) Active geomorphosites and educational application: an itinerary along Trebbia River (Northern Apennines, Italy). In: Reynard E, Laigre L, Kramar N (eds), Les géosciences au service de la société. Actes du colloque en l'honneur du Professeur Michel Marthaler, 24-26 juin 2010, Lausanne. Institut de géographie, Université de Lausanne. Géovision 37:219-234

Bollati I, Pelfini M, Pellegrini L (2012a) A geomorphosites selection method for educational purposes: a case study in Trebbia Valley (Emilia Romagna, Italy). Geogr Fis Din Quat 35:23-35. doi:10. 4461/GFDQ.2012.35.3

Bollati I, Della Seta M, Pelfini M, Del Monte M, Fredi P, Lupia Palmieri E (2012b) Dendrochronological and geomorphological investiga- tions to assess water erosion and mass wasting processes in the Apennines of Southern Tuscany (Italy). Catena 90:1-17

Bruno DE, Perrotta P (2012) A geotouristic proposal for Amendolara territory (northern ionic sector of Calabria, Italy). Geoheritage 4(3):139151

Calzolari C, Torri D, Del Sette M, Maccherini S, Bryan R (1997) Evoluzione dei suoli e processi di erosione su biancane: il caso delle biancane de la foce (Val d'Orcia, Siena). Boll Soc Ital Sci Suolo 8: 185-203

Carmignani L, Decandia FA, Fantozzi PL, Lazzarotto A, Liotta D, Meccheri M (1994) Tertiary extensional tectonics in Tuscany (Northern Apennines, Italy). Tectonophysics 238:295-315

Castaldini D, ValdatiJ, Ilies DC, Chiriac C, Bertogna I(2005) Geo-tourist map of the natural reserve of Salse di Nirano (Modena Apennines, northern Italy). Il Quaternario 18(1):245-255

Cendrero A, Panizza M (1999) Geomorphology and environmental im- pact assessment: an introduction. Suppl Geogr Fis Din Quat III/3: 167-172

Ciccacci S, Galiano M, Roma MA, Salvatore MC (2008) Morphological analysis and erosion rate evaluation in badlands of Radicofani area (Southern Tuscany-Italy). Catena 74:87-97

Cook ER (1985) A time series approach to tree-ring standardization. Ph.D. thesis, The University of Arizona, Tucson

Coutterand S (2012) The Lateglacial of Hérens valley (Valais, Switzerland): palaeogeographical and chronological reconstructions of deglaciation stages. Special Issue for the XVIII INQUA Congress in Bern, Switzerland 101XVIII INQUA Congress, 21st-27th July 2011, Bern, Switzerland. Quater Int 60(3):279-280

De Martonne E (1926) Aréisme et indice d'aridité. C R 182(23):1395- 1398

Della Seta M, Del Monte M, Fredi P,Lupia Palmieri E (2007) Direct and indirect evaluation of denudation rates in Central Italy. Catena 71: 21-30

Della Seta M, Del Monte M, Fredi P, Lupia PE (2009) Space-time vari- ability of denudation rates at the catchment and hillslope scales on the Tyrrhenian side of Central Italy. Geomorphology 107:161-177

Dorthe -Monachon C (1993) Etude des stades tardiglaciaires des vallées de la rive droite du Rhône entre Loèche et Martigny. Inst Géog Univ Lausanne Trav Rech 10

Gabbrielli A(1960) I calanchi di Monte Oliveto Maggiore el'inizio della loro sistemazione idraulica e forestale. Ital For Mont XV:183-189

Gärtner H (2007) Tree roots-methodological review and new develop- ment in dating and quantifying erosive processes. Geomorphology 86:243251

Gärtner H, Schweingruber FH, Dikau R (2001) Determination of erosion rates by analyzing structural changes in the growth pattern of ex- posed roots. Dendrochronologia 19:81-91

Guida D, Pelfini M, Santilli M (2008) Geomorphological and dendro- chronological analyses of a complex landslide in the Southern Apennines. Geogr Ann A 90(3):211-226 
Heck P (1985) Lady with hats. Geogr Mag 481-484

Holmes RL, Adams RK, Fritts HC (1986) Tree-ring chronologies of North America: California, Eastern Oregon and Northern Great Basin with procedures used in the chronology development work including user manual for computer program COFECHA and ARSTAN. Chronology Series VI, University of Arizona, Laboratory of tree-ring research, Tucson, USA

Hooke JM (1994) Strategies for conserving and sustaining dynamic geo- morphological sites. In: O’Halloran D, Green C, Harley M, Stanley M, Knill J (eds) Geological and landscape conservation. Geological Society, London, pp 191-195

Hupp C, Carey WP (1990) Dendrogeomorphic approach to estimating slope retreat. Geology 18(7):658-661

Lambiel C, Maillard B, Kummert M, Reynard E (2015) Geomorphology of the Hérens valley (Swiss Alps). J Maps 1-13

Liotta D (1996) Analisi del settore centromeridionale del bacino pliocenico di Radicofani (Toscana meridionale). Boll Soc Geol Ital 115:115143

Panizza M (2001) Geomorphosites: concepts, methods and examples of geomorphological survey. Chin Sci Bull 46:4-6

Panizza M, Piacente S (2003) Geomorfologia culturale. Pitagora Ed, Bologna

Pelfini M, Bollati I (2014) Geoheritage and geomorphosites ongoing changes: concepts and implications for tourism and cultural fruition. Quaest Geogr 33(1):131-143

Pelfini M, Santilli M (2006) Dendrogeomorphological analyses on ex- posed roots along two mountain hiking trails in the Central Italian Alps. Geogr Ann A 88(3):223-236

Pelfini M, Brandolini P, Carton A, Piccazzo M (2009) Geo-tourist and geomorphological risk/impact. In: Reynard E, Coratza P, Regolini- Bissig G (eds) Geomorphosites. Pfeil Verlag, München,pp 131-143

Perna G (1963) Piramidi di terra e piramidi di erosione nel Trentino - Alto Adige. Special Volume. Memorie del Museo di Storia Naturale della Venezia Tridentina. XIV(II)

Poesen JW, Torri D, Bunte K (1994) Effects of rock fragments on soil erosion by water at different spatial scales: a review. Catena 23:141- 166

Regent Instruments INC (2001) Windendro 2001 user manual. Quebec, Canada

Reynard E (2004) Géotopes, géo(morpho)sites et paysages géomorphologiques. In: Reynard E, Pralong JP (eds) Paysages géomorphologiques. Université de Lausanne, Institut de Géographie. Trav Rech 27:124-136

Reynard E, Coratza P (2013) Scientific research on geomorphosites. A review of the activities of the IAG working group on geomorphosites over the last twelve years. Geogr Fis Din Quat 36: 159-168

Reynard E, Coratza P, Regolini-Bissig G (2009) Geomorphosites. Pfeil Verlag, München

Reynard E, Berger JP, Constandache M, Felber M, Grangier L, Häuselmann P,Jeannin PY, Martin S(2012) Révision de l'inventaire des géotopes suisses: rapport final. Lausanne, Groupe de travail pour les géotopes en SuisseReynard E, Perret A, Bussard J, Grangier L, Martin S (2015) Integrated approach for the inventory and management of geomorphological heritage at the regional scale. Geoheritage, pp 1-18.doi:10.1007/ s12371-015-0153-0

Rinn F (1996) TSAP. Time Series Analysis and Presentation. Version 3.0 Reference Manual, Heidelberg

Sacco F (1934) Le Alpi. T.C.I ., Milan

Salvini R (2008) Analisi morfometriche delle Crete Senesi mediante re- mote sensing and GIS. Mem Descr Carta Geol Ital 78:245-252

Schweingruber FH (1996) Tree rings and environment: dendroecology. Haupt, Berne

Smith BJ, Orford JD, Nicholas BL (2009) Management challenges of a dynamic geomorphosite: climate change and the Giant's Causeway World Heritage Site. In: Reynard E, Coratza P, Regolini-Bissig G (eds) Geomorphosites. Pfeil Verlag, München, pp 145-162

Stoffel M, Corona C, Ballesteros-Cánovas JA, Bodoque JM (2013) Dating and quantification of erosion processes based on exposed roots. Earth Sci Rev 123:18-34

Timell TE(1986) Compression wood in gymnosperms. Springer Verlag, Berlin

TorriD, Bryan R(1997) Micropiping processes and biancana evolution in southeast Tuscany, Italy. Geomorphology 20(3):219-235

Torri D, Regüés D, Pellegrini S, Bazzoffi P (1999) Within-storm soil surface dynamics and erosive effects of rainstorms. Catena 38(2): 131-150

Vergari F, Della Seta M, Del Monte M, Fredi P, Lupia Palmieri E (2013) Long- and short-term evolution of several Mediterranean denuda- tion hot spots: the role of rainfall variations and human impact. Geomorphology 183:14-27

Yang G, Yanga Z, Zhanga X, Tiana M, Chenb A, Gea Z, Pinga Y, Nia Z (2011) Rs-based geomorphic analysis of Zhangjiajie sandstone peak forest Geopark, China. J Cult Herit 12(1):88-97

Zachar D

1982) Soil

erosion.

Elsevier,

Amsterdam 